\title{
COVID-19 and Herpes Simplex Virus Infection: A Cross-Sectional
}

\section{Study}

Mohammed Shanshal ${ }^{1,}{ }^{*}$, Hayder Saad Ahmed ${ }^{2, \wedge}$

${ }^{1}$ Basildon and Thurrock Hospitals NHS Foundation Trust, Department of Dermatology, UK

${ }^{2}$ University of Tikrit, College of Medicine, Department of Dermatology and Venereology, Iraq

* Specialist dermatologist, MBChB, FABMS - Dermatology

^Specialist dermatologist, MBChB, FIBMS - Dermatology

Corresponding author:

Mohammed Shanshal, MBChB, FABMS - Dermatology

Specialist Dermatologist at Basildon University Hospital, UK

Email: Mohammed.Shanshal@nhs.net

ORCID Id: https://orcid.org/0000-0003-2877-5919

Word count: 1292

Abstract word count: 215

Number of figures: 3

Number of tables: 2

Number of references: 36

Conflicts of interest: None

Funding sources: None

Patient privacy and ethical use of images:

The patients in this manuscript have provided written informed consent for the publication of their case details, including the use of images. 


\section{Abstract}

\section{Background}

Despite being variable and poorly characterized, the reported cutaneous manifestations of COVID-19 are of increasing concern.

\section{Aim of the Study}

This study aimed to assess the prevalence and possible association between COVID-19 and herpes simplex virus (HSV) infection.

\section{Patients and methods}

A 9-item questionnaire was sent to 120 PCR-confirmed COVID-19 patients with a response rate of $66.67 \%$. This cross-sectional observational study included 80 patients with mild to moderate COVID-19 infection who did not require hospitalization or steroid therapy.

\section{Results}

One or more HSV infections were observed in 28 patients (35\%) with COVID-19 infection, including 10 males (35.7\%) and 18 females (64.29\%). Of the 28 patients, fever was reported in 17 patients (75\%) during COVID-19. Most of the respondents (78\%) described a single HSV reactivation, $14.29 \%$ had 2 attacks, and $7.14 \%$ experienced 3 attacks. Compared to previous non-COVID-19 related 
medRxiv preprint doi: https://doi.org/10.1101/2021.07.09.21260217; this version posted July 12,2021 . The copyright holder for this preprint (which was not certified by peer review) is the author/funder, who has granted medRxiv a license to display the preprint in perpetuity.

All rights reserved. No reuse allowed without permission.

HSV reactivation, the COVID-19 related attacks were more severe in 12 patients (42.85\%), equally severe in 5 patients (17.85\%) and less severe in 1 patient (3.57\%). Interestingly, 10 patients (35.71\%) developed an initial symptomatic HSV attack during COVID-19 infection.

\section{Conclusions}

This study demonstrated a possible association between COVID-19 infection and primary HSV infection and/or reactivation. The COVID-19 direct neuronal effect in addition to COVID-19 related psychological stress, fever and immunological dysregulation could play a potential role.

\section{Keywords}

COVID-19, Herpes Simplex infection, Dermatologic manifestations of COVID-19 
medRxiv preprint doi: https://doi.org/10.1101/2021.07.09.21260217; this version posted July 12,2021 . The copyright holder for this preprint (which was not certified by peer review) is the author/funder, who has granted medRxiv a license to display the preprint in perpetuity.

\section{Introduction}

For about a year now, the world has been under the grip of the COVID-19 pandemic. More than 183 million cases and approximately 4 million deaths have been reported globally (1).

COVID-19 is caused by severe acute respiratory syndrome coronavirus 2 (SARS CoV2), a member of the Coronaviridae family. In the 21st century, two other major respiratory disease outbreaks were caused by closely related coronaviruses, including severe acute respiratory syndrome (SARS) and Middle East respiratory syndrome (MERS) (2).

Although respiratory manifestations seem to be predominant, an increasing number of COVID-19 related cutaneous manifestations have been reported, including maculopapular, urticarial, purpuric, chilblain-like and vesicular eruptions. Other less commonly reported lesions include livedo reticularis-like, erythema multiforme-like, papulosquamous, necrotic lesions and gangrene (3) (4) (5).

Herpes simplex virus (HSV), an enveloped DNA virus belonging to the Herpesviridae family, is a ubiquitous pathogen that commonly infects humans. It has been estimated that two-thirds of the population under 50 years of age are infected with herpes simplex virus type 1 (6). After primary infection, HSV 
medRxiv preprint doi: https://doi.org/10.1101/2021.07.09.21260217; this version posted July 12,2021 . The copyright holder for this preprint (which was not certified by peer review) is the author/funder, who has granted medRxiv a license to display the preprint in perpetuity.

All rights reserved. No reuse allowed without permission.

can establish a life-long latent infection in the sensory ganglia via retrograde transport through peripheral neurons. The virus can be reactivated periodically in response to various stimuli including psychological stress, fever, sunlight, hormonal imbalance, immunosuppression and surgical resection (7) (8). When HSV-1 infection is symptomatic, the most common clinical manifestations are gingivostomatitis and pharyngitis in children and adults, respectively, whereas Herpes labialis "cold sore" represents the most frequent sign of HSV-1 reactivation (9) (10). Other less frequent cutaneous manifestations of HSV-1 include herpetic whitlow, erythema multiform, eczema herpeticum, and herpes gladiatorum (11) (12) (13) (14). 
medRxiv preprint doi: https://doi.org/10.1101/2021.07.09.21260217; this version posted July 12,2021 . The copyright holder for this preprint (which was not certified by peer review) is the author/funder, who has granted medRxiv a license to display the preprint in perpetuity.

\section{Patients and methods}

A cross-sectional observational study was conducted at Baghdad Teaching Hospital, where data were obtained from an online survey conducted between August and October 2020. Eligibility criteria were as follows: any age, PCRconfirmed mild to moderate COVID-19 infection, not admitted to the RCU or required steroid therapy. A 9-item online questionnaire was created and sent by email to 120 patients with PCR-confirmed mild to moderate COVID-19. The survey included a range of measures to examine the prevalence, severity and timing of herpes simplex during COVID-19 infection. Participants reported their age, sex, COVID-19 status, history and severity of past HSV infection, history and severity of HSV during COVID-19, history of fever and HSV infection timing during COVID-19. The diagnosis of herpes labialis was based on the clinical features. 
medRxiv preprint doi: https://doi.org/10.1101/2021.07.09.21260217; this version posted July 12,2021 . The copyright holder for this preprint (which was not certified by peer review) is the author/funder, who has granted medRxiv a license to display the preprint in perpetuity.

\section{Results}

The questionnaire was completed by 80 out of 120 patients who received an online survey with a response rate of $66.67 \%$. The mean age and SD were $33.87 \pm 9.46$ years. Twenty-eight patients (35\%) reported single or multiple episodes of HSV reactivation (Table 1 ). The majority of patients ( $n=24,78.57 \%)$ reported a single attack of HSV reactivation during their COVID-19 infection, while $14.29 \%$ and $7.14 \%$ experienced two or more attacks, respectively (Figure 1). Of the 28 patients, $18(46.29 \%)$ reported recurrent attacks of HSV reactivation before COVID-19 infection. Compared to previous attacks, COVID19 related HSV reactivation was more severe, equally severe or less severe in $42.86 \%, 17.68 \%$ and $3.57 \%$, respectively. The onset of HSV infection varies among individuals after the onset of COVID-19. The mean time of onset of the first HSV infection was $8+6.48$ days while the onset on the second and third attacks were $11+3.44$ and $22+3.53$ days, respectively (Table 2 ). 
medRxiv preprint doi: https://doi.org/10.1101/2021.07.09.21260217; this version posted July 12,2021 . The copyright holder for this preprint (which was not certified by peer review) is the author/funder, who has granted medRxiv a license to display the preprint in perpetuity.

All rights reserved. No reuse allowed without permission.

Table 1: Frequency distribution of the COVID-19 related HSV infection, fever and previous HSV infection among included patients

\begin{tabular}{|l|l|l|}
\hline & Yes & No \\
\hline $\begin{array}{l}\text { Did the patient get an } \\
\text { attack of herpes simplex } \\
\text { during the COVID-19 } \\
\text { infection? }\end{array}$ & $\begin{array}{r}28(35 \%) \\
- \text { Male } 10(35.71 \%)\end{array}$ & $52(65 \%)$ \\
\hline $\begin{array}{l}\text { Did the patient get a } \\
\text { fever during the attack? }\end{array}$ & $21(75 \%)$ & $7(25 \%)$ \\
\hline $\begin{array}{l}\text { Does the patient have } \\
\text { recurrent attacks of HSV } \\
\text { before COVD-19? }\end{array}$ & $18(64.29 \%)$ & $10(35.71 \%)$ \\
\hline $\begin{array}{l}\text { Was the COVID-19 } \\
\text { related HSV the first } \\
\text { symptomatic HSV } \\
\text { attack? }\end{array}$ & $10(35.71 \%)$ & $18(64.29 \%)$ \\
\hline
\end{tabular}

Table 2: The mean time of HSV onset after acquiring COVID-19

\begin{tabular}{|l|c|c|c|}
\hline $\begin{array}{l}\text { Timing of HSV } \\
\text { reactivation } \\
\text { (days) }\end{array}$ & No. & Mean & SD \\
\hline First attack & 28 & 8 & 6.48 \\
\hline Second attack & 6 & 11 & 3.44 \\
\hline Third attack & 2 & 22 & 3.53 \\
\hline
\end{tabular}




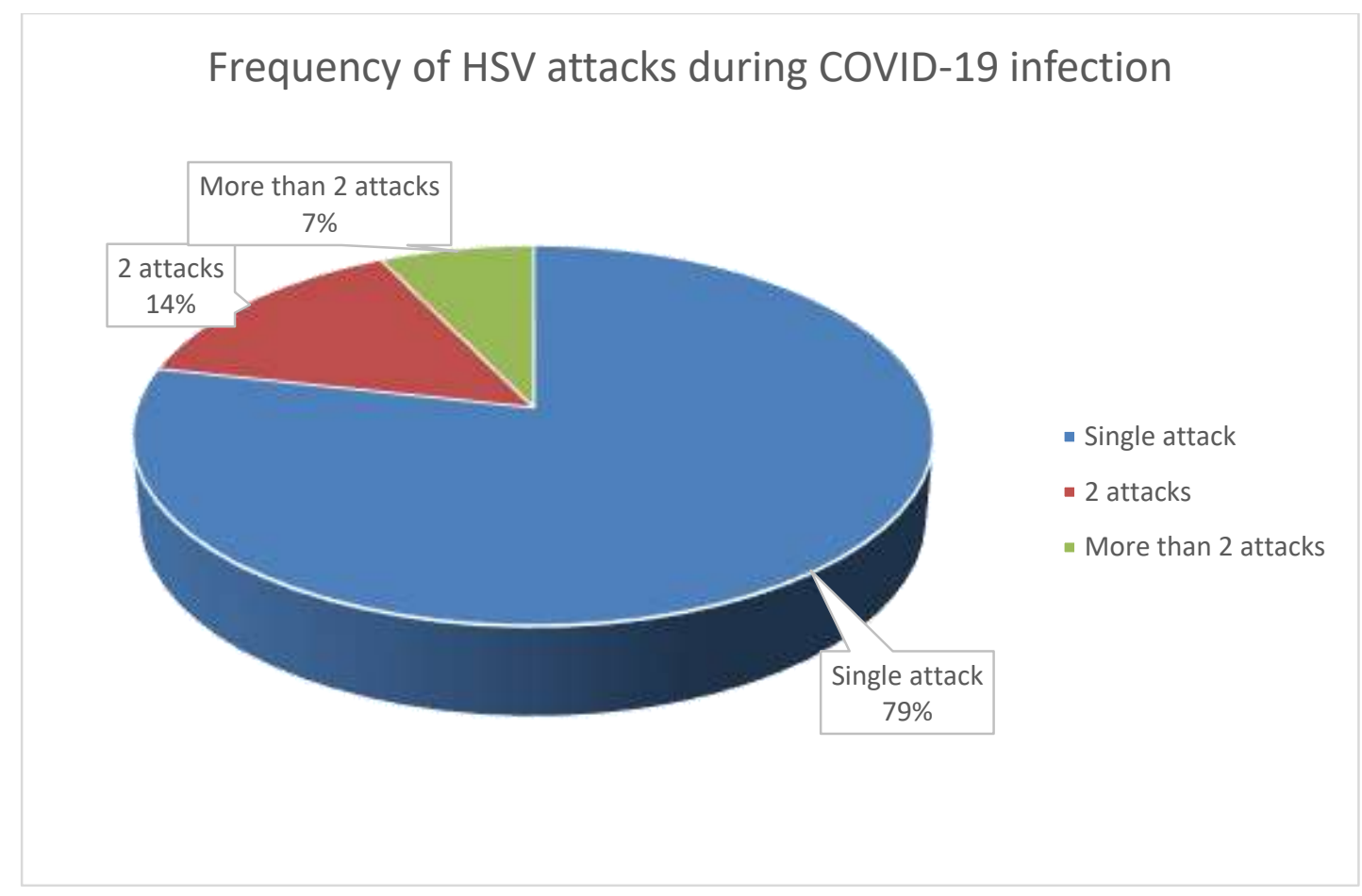

Figure 1: Frequency of HSV infection among COVID-10 patients.

\section{Discussion}

Depending on the host cell type, HSV can produce lytic and latent lytic stages, where the lytic stage can occur in various tissue types, while the latent stage tends to occur in neuronal tissues (15). The lytic stage can result from viral replication in the epithelial cells of the oral and genital mucosa, eye or skin producing labial herpes (cold sores), genital herpes, herpetic keratitis and herpetic whitlow or eczema herpeticum, respectively. HSV is a neurotropic virus that can establish latency in the neuronal dendrites of the sensory ganglia 
medRxiv preprint doi: https://doi.org/10.1101/2021.07.09.21260217; this version posted July 12,2021 . The copyright holder for this preprint (which was not certified by peer review) is the author/funder, who has granted medRxiv a license to display the preprint in perpetuity. All rights reserved. No reuse allowed without permission.

that supply primary epithelial tissues (16). The immune system plays a vital role in controlling HSV replication, driving the virus into a latency state for prolonged periods (17).

A total of 28 patients with PCR-confirmed COVID-19 (35\%) reported single or multiple attacks of HSV infection (Figure), including 18 females (64.29\%) and 10 males (35.71\%) with a mean age of 38.4 years and a standard deviation of 13.64. The number of females surpassed that of males; as the rate of HSV seropositivity is slightly higher in females aged between 15 and 39 years than in males (18) (19). 
Four patho-mechanisms were proposed to explain the higher frequency of herpes reactivation during COVID19 (Figure 3):

1- COVID-19 related immune dysregulation: COVID19 is associated with unique immune dysregulation, including CD4 cell and NK cell cytopenias and sustained inflammatory interleukins stimulation such as interleukin-6 (IL-6) and tumor necrosis factor- $\alpha$ (TNF- $\alpha$ ) (20). Immune dysregulation causes HSV-1 to burst from latency and travel anterogradely to epithelial surfaces, where viral replication and lytic stages occur (21). Interestingly, a potential relationship between the cytokine interleukin (IL)-6, which is overrepresented in COVID19 patients (22) (23) and reactivation of herpes simplex virus has been proposed (24). Compared to mice receiving control antibodies, HSV-latently infected mice 
medRxiv preprint doi: https://doi.org/10.1101/2021.07.09.21260217; this version posted July 12,2021 . The copyright holder for this preprint (which was not certified by peer review) is the author/funder, who has granted medRxiv a license to display the preprint in perpetuity.

injected with neutralizing anti-IL-6 antibodies show a lower frequency of virus reactivation (25) (26).

2- Direct effect of COVID19 on the neurons: COVID19 has a potential neurotropic mechanism that explains the neurological manifestations associated with COVID-19 like loss of taste and smell, headache, dizziness, meningitis, cerebrovascular disease and acute Guillain-Barré syndrome. SARSCoV-2 has an affinity to bind to the angiotensin-converting enzyme 2 (ACE2) receptor; hence, cells that express ACE2 like neurons and glial cells are vulnerable to SARS-CoV-2 infection (27) (28).

3- COVID-19 related psychological stress: COVID19 is associated with significant psychological and physical stress. It has been postulated that stress impairs the cytotoxic T cell surveillance of latently infected neurons, resulting in replication and activation of latent viruses (29) (30) (31). Other hypotheses include stress-related relapse of catecholamines and glucocorticoids (stress hormones) and their direct and indirect effects on HSV reactivation (32).

4- COVID-19 related fever: Seventy-five percent of patients with HSV in the survey reported fever. Fever is a strongly linked environmental trigger of human HSV reactivation either through a direct effect on latently infected neurons and/or the secretion of pyrogenic cytokines, including IL-6 (33) (34). 
medRxiv preprint doi: https://doi.org/10.1101/2021.07.09.21260217; this version posted July 12,2021 . The copyright holder for this preprint (which was not certified by peer review) is the author/funder, who has granted medRxiv a license to display the preprint in perpetuity.

All rights reserved. No reuse allowed without permission.

Le Balc'h et al. suggested that COVID-19 infection could be a risk factor for Herpesviridae reactivation and subsequent pulmonary infection in patients with COVID-19 severe acute respiratory distress syndrome (35).

Elsaie et al described two cases of varicella-zoster virus (VZV, another member of the Herpesviridae family) during COVID-19 infection. After primary infection, VZV remains dormant in neuronal tissues and is reactivated in a similar fashion to HSV (36). 
medRxiv preprint doi: https://doi.org/10.1101/2021.07.09.21260217; this version posted July 12, 2021. The copyright holder for this preprint (which was not certified by peer review) is the author/funder, who has granted medRxiv a license to display the preprint in perpetuity.

All rights reserved. No reuse allowed without permission.
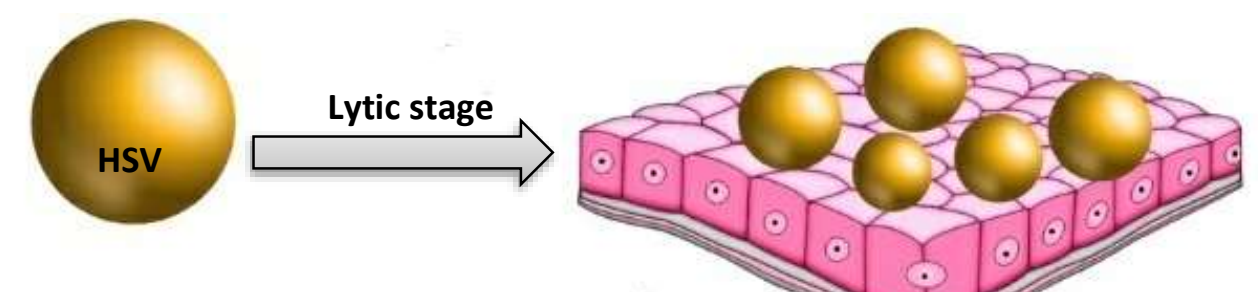

COVID19 infection
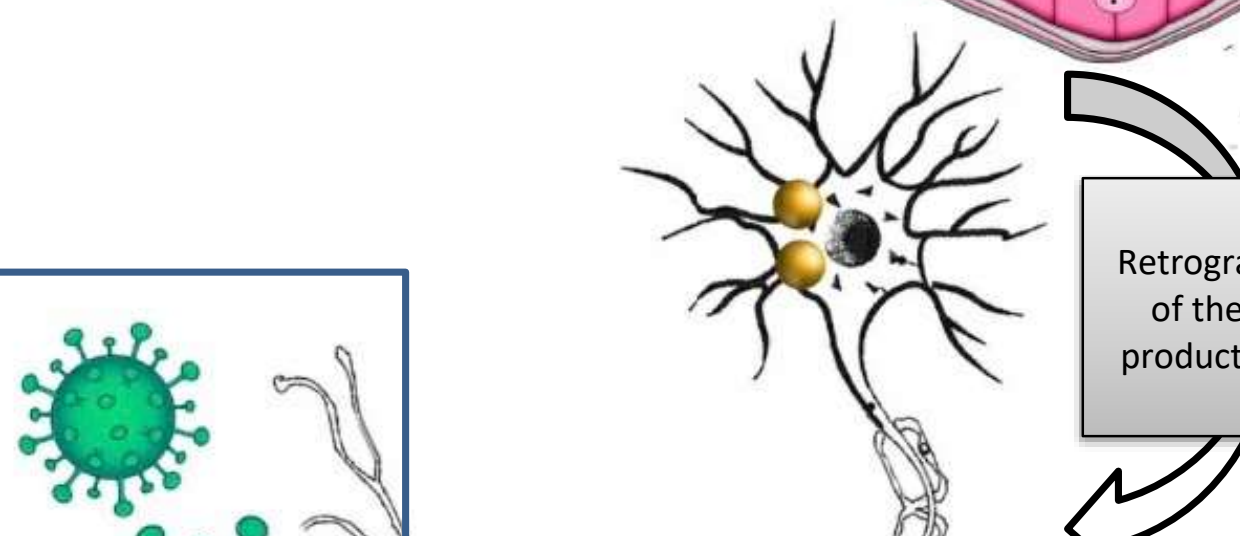

Latency stage

Retrograde transport, Restriction of the transcriptional profile, production of latency-associated

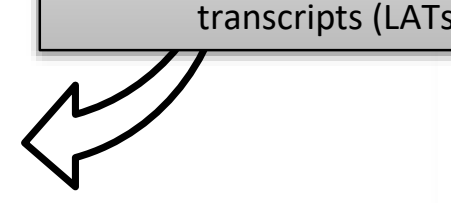

Immune dysregulation

$>$ Direct effect on neurons

$>$ Psychological stress

$>$ Fever

Reactivation stage

Upregulation of the lytic genes, HSV 1 reactivation from latency, antegrade viral progression

\section{Figure 3}

Proposed patho-mechanisms of HSV reactivation during COVID-19 infection.

After primary infection, HSV can remain in the latent stage for several years. COVID-19 related immune dysregulation, fever, stress and the direct neuronal effect of the virus can result in upregulation of HSV lytic genes, reactivation of the latent virus and viral replication. 
medRxiv preprint doi: https://doi.org/10.1101/2021.07.09.21260217; this version posted July 12,2021 . The copyright holder for this preprint (which was not certified by peer review) is the author/funder, who has granted medRxiv a license to display the preprint in perpetuity.

All rights reserved. No reuse allowed without permission.

\section{Conclusion}

COVID-19 related immune dysregulation, psychological stress, fever and direct neuronal effects might play a role in the activation of different cellular processes that result in increased HSV Iytic gene expression and reactivation of the virus. Herpes simplex reactivation in patients with new respiratory symptoms could serve as a new clue of the emerging COVID-19 infection.

\section{Limitation of the study}

Recall bias is expected, and further prospective or retrospective case-control studies are advisable. 
medRxiv preprint doi: https://doi.org/10.1101/2021.07.09.21260217; this version posted July 12,2021 . The copyright holder for this preprint (which was not certified by peer review) is the author/funder, who has granted medRxiv a license to display the preprint in perpetuity.

\section{References}

1- World Health Organization (WHO), Coronavirus disease (COVID-19) pandemic. $\quad$ Accessed $\quad$ on $\quad 14 \quad$ Nov 2020

\section{https://www.who.int/emergencies/diseases/novel-coronavirus-2019}

2- Dawood FS, Ricks P, Njie GJ, Daugherty M, Davis W, Fuller JA, Winstead A, McCarron M, Scott LC, Chen D, Blain AE. Observations of the global epidemiology of COVID-19 from the prepandemic period using web-based surveillance: a cross-sectional analysis. Lancet Infect Dis. 29 Jul 2020;20(11):1255-62.

3- Galván Casas C, Catala AC, Carretero Hernández G, Rodríguez-Jiménez $P$, Fernández-Nieto D, Rodríguez-Villa Lario A, Navarro Fernández I, RuizVillaverde R, Falkenhain-López D, Llamas Velasco M, García-Gavín J. Classification of the cutaneous manifestations of COVID-19: a rapid prospective nationwide consensus study in Spain with 375 cases. Br J Dermatol. 2020 Jul;183(1):71-7.

4- Freeman EE, McMahon DE, Lipoff JB, Rosenbach M, Kovarik C, Desai SR, Harp J, Takeshita J, French LE, Lim HW, Thiers BH. The spectrum of COVID-19associated dermatologic manifestations: an international registry of 716 patients from 31 countries. J Am Acad Dermatol. 2020 Oct; 38(4): 1118-29. 
medRxiv preprint doi: https://doi.org/10.1101/2021.07.09.21260217; this version posted July 12,2021 . The copyright holder for this preprint (which was not certified by peer review) is the author/funder, who has granted medRxiv a license to display the preprint in perpetuity. All rights reserved. No reuse allowed without permission.

5- Zhao Q, Fang X, Pang Z, Zhang B, Liu H, Zhang F. COVID-19 and cutaneous manifestations: a systematic review. J Eur Acad Dermatol Venereol . 2020 Jun. https://doi.org/10.1111/jdv.16778.

6- World Health Organization, Globally, an estimated two-thirds of the population under 50 are infected with herpes simplex virus type 1; 28 October 2015. Accessed on 14 Nov 2020.

https://www.who.int/news/item/28-10-2015-globally-an-estimated-twothirds-of-the-population-under-50-are-infected-with-herpes-simplex-virustype1?fbclid=IwAR3yhp3euxXtLrzQKSuXXLk4nynFMPOCXagp2uOo7qJ9619bjZU $\underline{\text { RIRDt4d8 }}$

7- Stoeger T, Adler H. "Novel" Triggers of Herpesvirus Reactivation and Their Potential Health Relevance. Front. Microbiol. 2019 Jan 7;9:3207.

8- Suzich JB, Cliffe AR. Strength in diversity: Understanding the pathways to herpes simplex virus reactivation. j.virol. 2018 Sep 1;522:81-91.

9- Bernstein DI, Bellamy AR, Hook III EW, Levin MJ, Wald A, Ewell MG, Wolff PA, Deal CD, Heineman TC, Dubin G, Belshe RB. Epidemiology, clinical presentation, and antibody response to primary infection with herpes simplex 
medRxiv preprint doi: https://doi.org/10.1101/2021.07.09.21260217; this version posted July 12,2021 . The copyright holder for this preprint (which was not certified by peer review) is the author/funder, who has granted medRxiv a license to display the preprint in perpetuity. All rights reserved. No reuse allowed without permission.

virus type 1 and type 2 in young women. Clinical infectious diseases. 2013 Feb 1;56(3):344-51.

10- Spruance SL, Overall Jr JC, Kern ER, Krueger GG, Pliam V, Miller W. The natural history of recurrent herpes simplex labialis: implications for antiviral therapy. New England Journal of Medicine. 1977 Jul 14;297(2):69-75.

11- Mancao MY, Sindel LJ, Richardson PH, Silver FM. Herpetic croup: two case reports and a review of the literature. Acta Paediatrica. 1996 Jan;85(1):118-20.

12- Ng PP, Sun YJ, Tan HH, Tan SH. Detection of herpes simplex virus genomic DNA in various subsets of erythema multiforme by polymerase chain reaction. Dermatology. 2003;207(4):349-53.

13- Wollenberg A, Wetzel S, Burgdorf WH, Haas J. Viral infections in atopic dermatitis: pathogenic aspects and clinical management. Journal of Allergy and Clinical Immunology. 2003 Oct 1;112(4):667-74.

14- Anderson BJ. The epidemiology and clinical analysis of several outbreaks of herpes gladiatorum. Medicine and science in sports and exercise. 2003 Nov $1 ; 35(11): 1809-14$

15- Brown JC. Herpes simplex virus latency: the DNA repair-centered pathway. Advances in virology. 2017 Jan 1;2017. 
medRxiv preprint doi: https://doi.org/10.1101/2021.07.09.21260217; this version posted July 12, 2021. The copyright holder for this preprint (which was not certified by peer review) is the author/funder, who has granted medRxiv a license to display the preprint in perpetuity. All rights reserved. No reuse allowed without permission.

16- Grinde B. Herpesviruses: latency and reactivation-viral strategies and host response. Journal of oral microbiology. 2013 Jan 1;5(1):22766.

17- Egan KP, Wu S, Wigdahl B, Jennings SR. Immunological control of herpes simplex virus infections. Journal of neurovirology. 2013 Aug 1;19(4):328-45.

18- Pebody RG, Andrews N, Brown D, Gopal R, De Melker H, François G, Gatcheva N, Hellenbrand W, Jokinen S, Klavs I, Kojouharova M. The seroepidemiology of herpes simplex virus type 1 and 2 in Europe. Sexually transmitted infections. 2004 Jun 1;80(3):185-91.

19- Rabenau H, Buxbaum S, Preiser W, Weber B, Doerr H. Seroprevalence of herpes simplex virus types 1 and type 2 in the Frankfurt am Main area, Germany. Medical microbiology and immunology. 2002 Mar 1;190(4):153-60.

20- Giamarellos-Bourboulis EJ, Netea MG, Rovina N, Akinosoglou K, Antoniadou A, Antonakos N, Damoraki G, Gkavogianni T, Adami ME, Katsaounou P, Ntaganou M. Complex immune dysregulation in COVID-19 patients with severe respiratory failure. Cell host \& microbe. 2020 Apr 21.

21- Parker ZM, Pasieka TJ, Parker GA, Leib DA. Immune-and nonimmunecompartment-specific interferon responses are critical determinants of herpes simplex virus-induced generalized infections and acute liver failure. Journal of virology. 2016 Dec 1;90(23):10789-99. 
medRxiv preprint doi: https://doi.org/10.1101/2021.07.09.21260217; this version posted July 12, 2021. The copyright holder for this preprint (which was not certified by peer review) is the author/funder, who has granted medRxiv a license to display the preprint in perpetuity. All rights reserved. No reuse allowed without permission.

22- Grifoni E, Valoriani A, Cei F, Lamanna R, Gelli AM, Ciambotti B, Vannucchi V, Moroni F, Pelagatti L, Tarquini R, Landini G. Interleukin-6 as prognosticator in patients with COVID-19: IL-6 and Covid-19. Journal of Infection. 2020 Jun 8.

23- Zhang ZL, Hou YL, Li DT, Li FZ. Laboratory findings of COVID-19: a systematic review and meta-analysis. Scandinavian journal of clinical and laboratory investigation. 2020 May 22:1-7.

24- Baker M, Noisakran S, Gebhardt BM, Kriesel JD, Carr DJ. The relationship between interleukin- 6 and herpes simplex virus type 1: implications for behavior and immunopathology. Brain, behavior, and immunity. 1999 Sep $1 ; 13(3): 201-11$

25- Kriesel JD, Ricigliano J, Spruance SL, Garza HH, Hill JM. Neuronal reactivation of herpes simplex virus may involve interleukin-6. Journal of neurovirology. 1997 Jan 1;3(6):441-8.

26- Kriesel JD, Gebhardt BM, Hill JM, Maulden SA, Hwang IP, Clinch TE, Cao X, Spruance SL, Araneo BA. Anti-interleukin-6 antibodies inhibit herpes simplex virus reactivation. Journal of Infectious Diseases. 1997 Apr 1;175(4):821-7.

27- Zhou Z, Kang H, Li S, Zhao X. Understanding the neurotropic characteristics of SARS-CoV-2: from neurological manifestations of COVID-19 to potential neurotropic mechanisms. Journal of Neurology. 2020 May 26:1. 
medRxiv preprint doi: https://doi.org/10.1101/2021.07.09.21260217; this version posted July 12, 2021. The copyright holder for this preprint (which was not certified by peer review) is the author/funder, who has granted medRxiv a license to display the preprint in perpetuity. All rights reserved. No reuse allowed without permission.

28- Zhou Z, Kang H, Li S, Zhao X. Understanding the neurotropic characteristics of SARS-CoV-2: from neurological manifestations of COVID-19 to potential neurotropic mechanisms. Journal of Neurology. 2020 May 26:1.

29- Freeman ML, Sheridan BS, Bonneau RH, Hendricks RL. Psychological stress compromises CD8+ $\mathrm{T}$ cell control of latent herpes simplex virus type 1 infections. The Journal of Immunology. 2007 Jul 1;179(1):322-8.

30- Stowe RP, Peek MK, Cutchin MP, Goodwin JS. Reactivation of herpes simplex virus type 1 is associated with cytomegalovirus and age. Journal of medical virology. 2012 Nov;84(11):1797-802.

31- Chida Y, Mao X. Does psychosocial stress predict symptomatic herpes simplex virus recurrence? A meta-analytic investigation on prospective studies. Brain, behavior, and immunity. 2009 Oct 1;23(7):917-25.

32- Ives AM, Bertke AS. Stress hormones epinephrine and corticosterone selectively modulate herpes simplex virus 1 (HSV-1) and HSV-2 productive infections in adult sympathetic, but not sensory, neurons. Journal of virology. 2017 Jul 1;91(13).

33- Roizman B, Knipe DM, Whitley RJ. Herpes simplex viruses, p 1823-1897. Fields virology, 6th ed. Lippincott Williams \& Wilkins, Philadelphia, PA. 2013. 
medRxiv preprint doi: https://doi.org/10.1101/2021.07.09.21260217; this version posted July 12,2021 . The copyright holder for this preprint (which was not certified by peer review) is the author/funder, who has granted medRxiv a license to display the preprint in perpetuity.

All rights reserved. No reuse allowed without permission.

34- Sawtell NM, Thompson RL. Rapid in vivo reactivation of herpes simplex virus in latently infected murine ganglionic neurons after transient hyperthermia. Journal of virology. 1992 Apr 1;66(4):2150-6.

35- Le Balc'h P, Pinceaux K, Pronier C, Seguin P, Tadié JM, Reizine F. Herpes simplex virus and cytomegalovirus reactivations among severe COVID-19 patients. Critical Care. 2020 Dec;24(1):1-3.

36- Elsaie ML, Youssef EA, Nada HA. Herpes zoster might be an indicator for Latent COVID 19 infection. Dermatologic Therapy. 2020 May 23:e13666. 